\title{
Scleromyxedema: a rare disorder and its treatment difficulties
}

\author{
Sandra Koleta Koronowska1', Agnieszka Osmola-Mańkowska², Oliwia Jakubowicz², Ryszard Żaba²
}

1Student Scientific Group at Department of Dermatology, Poznan University of Medical Sciences, Poland

Tutor: Agnieszka Osmola-Mańkowska MD, PhD

2Department of Dermatology, Poznan University of Medical Sciences, Poland

Head: Prof. Zygmunt Adamski MD, PhD

Postep Derm Alergol 2013; XXX, 2: 122-126

DOI: 10.5114/pdia.2013.34165

\begin{abstract}
Scleromyxedema is a rare progressive cutaneous mucinosis, usually associated with a systemic involvement and paraproteinemia. Its aetiology remains unknown. The therapeutic options include numerous treatment modalities, however, no standard treatment exists as the rarity of this disease prevents the execution of controlled therapeutic trials. This paper reports a case of a 38-year-old male with progressive scleromyxedema associated with gammopathy. Initially, the patient was treated with prednisolone and later etretinate was added to the therapeutic schedule with quite good clinical improvement. However, after 6 months of treatment, several adverse effects were observed: hypercholesterolemia, hypertriglyceridaemia and cataract of the right eye. The patient was consulted by dermatologists in Warsaw and Gdansk as well as by a haematologist. The patient was excluded from oncological treatment. Melphalan therapy was not recommended as it is associated with very toxic side effects. IVIG treatment (intravenous immunoglobulin) was not initiated because of financial issues. As the disease progressed, treatment with plasmapheresis was introduced. The patient received 4 cycles of the therapy. It was well-tolerated by the patient and gave satisfactory, but temporary results. In order to obtain long-lasting improvement the patient was treated with IVIG (21.0 g/dose for 5 consecutive days). This treatment modality seems to have resulted in a more stable improvement.
\end{abstract}

Key words: scleromyxedema, treatment, intravenous Immunoglobulin, plasmapheresis.

\section{Introduction}

Scleromyxedema (SM) is a rare progressive cutaneous mucinosis usually associated with a systemic involvement and paraproteinemia. It was first defined by Arndt and Gottron (1954) [1], then redefined by Rongioletti and Rebora (2001), as a disease characterised by a generalised papular and sclerodermoid eruption, monoclonal gammopathy (mostly lg- $\lambda$ paraproteinemia) and a triad of histological features: presence of mucin deposition within the upper and mid reticular dermis, fibroblast proliferation and fibrosis with the absence of a thyroid disorder [2] (Figure 1).

Scleromyxedema is a severe disorder that may be fatal. It is characterised by an excessive deposition of mucin in the connective tissue [3]. The deposits may stimulate the synthesis of collagen and glycosaminoglycans [1]. As a result, lichenoid papules are formed which cause thick- ening and hardening of the tissue [4]. Scleromyxedema has a chronic, disabling course because it is often associated with a systemic involvement of internal organs. Scleromyxedema is thought to have three main clinicopathological subsets: local, generalised and atypical [3]. The generalised form is often referred to as the "generalised lichen myxedematosus", and its course is much more severe than that of the other forms (Figure 2).

The prevalence of SM is equal in men and women. No standard treatment exists as the rarity of the disease has prevented the execution of controlled therapeutic trials. Until 2009, only 150 cases of patients suffering from scleromyxoedema were reported [5].

The skin appears to be elephant-like and forms linear folds. The papules tend to group in the neck and forehead area. Histopathological examination reveals numerous mucin deposits in papules and sclerotic malformations,

Address for correspondence: Sandra Koleta Koronowska, Student Scientific Group at Department of Dermatology, Poznan University of Medical Sciences, 49 Przybyszewskiego St, 60-355 Poznan, Poland, phone: +48 504006 321, e-mail: koronowska@op.pl Received: 9.08.2012, accepted: 24.10.2012. 
which consist of thickened collagen fibres. The mucin deposits are subtle in these lesions [1].

Numerous internal manifestations may occur in SM [6-8] (Table 1).

\section{Case report}

We report a case of a 38-year-old man with a 1.5-year history of scleromyxedema typically associated with light chain $\lambda$ IgG monoclonal gammopathy. He was first hospitalized in February 2011 due to severe pruritus of his feet and shanks, elbow, and carpal joint pain and sclerodactyly. Simultaneously erythema and small papules appeared on the skin of his face.

Cutaneous examination revealed small, symmetric, disseminated papules (of $1 \mathrm{~mm}$ in diameter). Waxy and firm papules were localised mainly on both arms. The patient also presented excessive and diffuse thickening of the skin on the face, especially surrounding the lips, which later led to facial expression impairment.

Radiological and ultrasonographic examinations were also performed to exclude any systemic involvement of the disease (chest X-ray, USG of abdomen). In laboratory investigation complete blood count was normal. Serum analysis indicated hyperproteinemia: IgG monoclonal gammopathy with $\lambda$ light chains were present. BenceJones protein was detected, however, further investigations excluded haematological disorders. Urine analysis was normal. Based on clinical manifestations, and histopathological and laboratory data, the diagnosis of scleromyxoedema with associated IgG- $\lambda$ was obtained.

As scleromyxedema leads to systemic involvement, the patient was consulted by several specialists: a haematologist, cardiologist, neurologist, ophthalmologist, internal medicine doctor and several dermatologists. The haematologist disqualified the patient from treatment with mel-

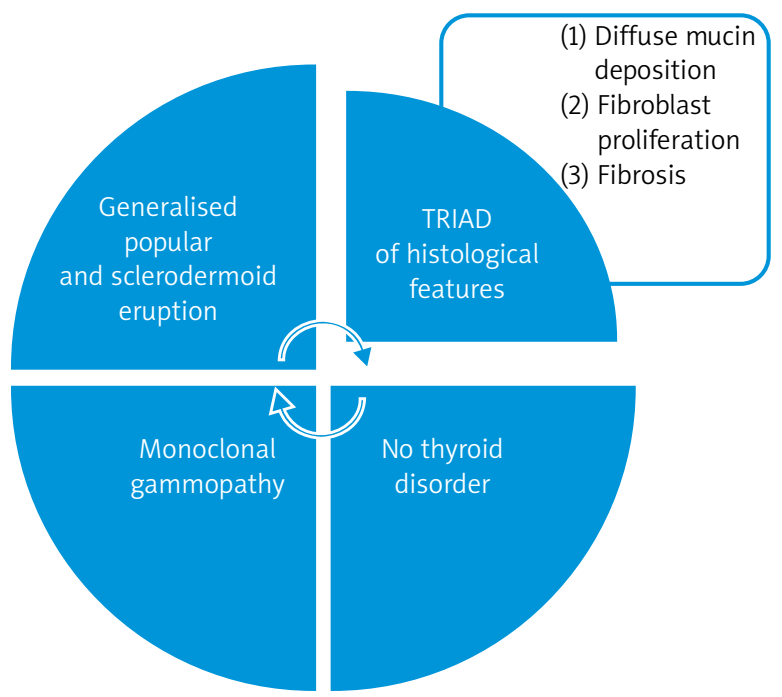

Figure 1. Diagnostic criteria of scleromyxedema

Figure 2. Chronic, potentially fatal course of scleromyxedema

Table 1. Internal manifestations of scleromyxedema

\begin{tabular}{ll}
\hline Type of involvement & Manifestation \\
\hline Muscular & Proximal myopathy, joint contractures, muscle weakness \\
\hline Neurological & Encephalopathy, peripheral neuropathy, coma \\
\hline Rheumatological & Joint pain, migrating arthritis, sclerodactyly, seronegative polyarthritis, carpal tunnel syndrome \\
\hline Pulmonary & Obstructive/restrictive lung disease, pulmonary hypertension \\
\hline Renal & Renal insufficiency \\
\hline Cardiovascular & Myocardial infarction, hypertension, atherosclerosis \\
\hline Ophthalmological & Corneal deposits, thinning of the eyelid, ectropion \\
\hline
\end{tabular}




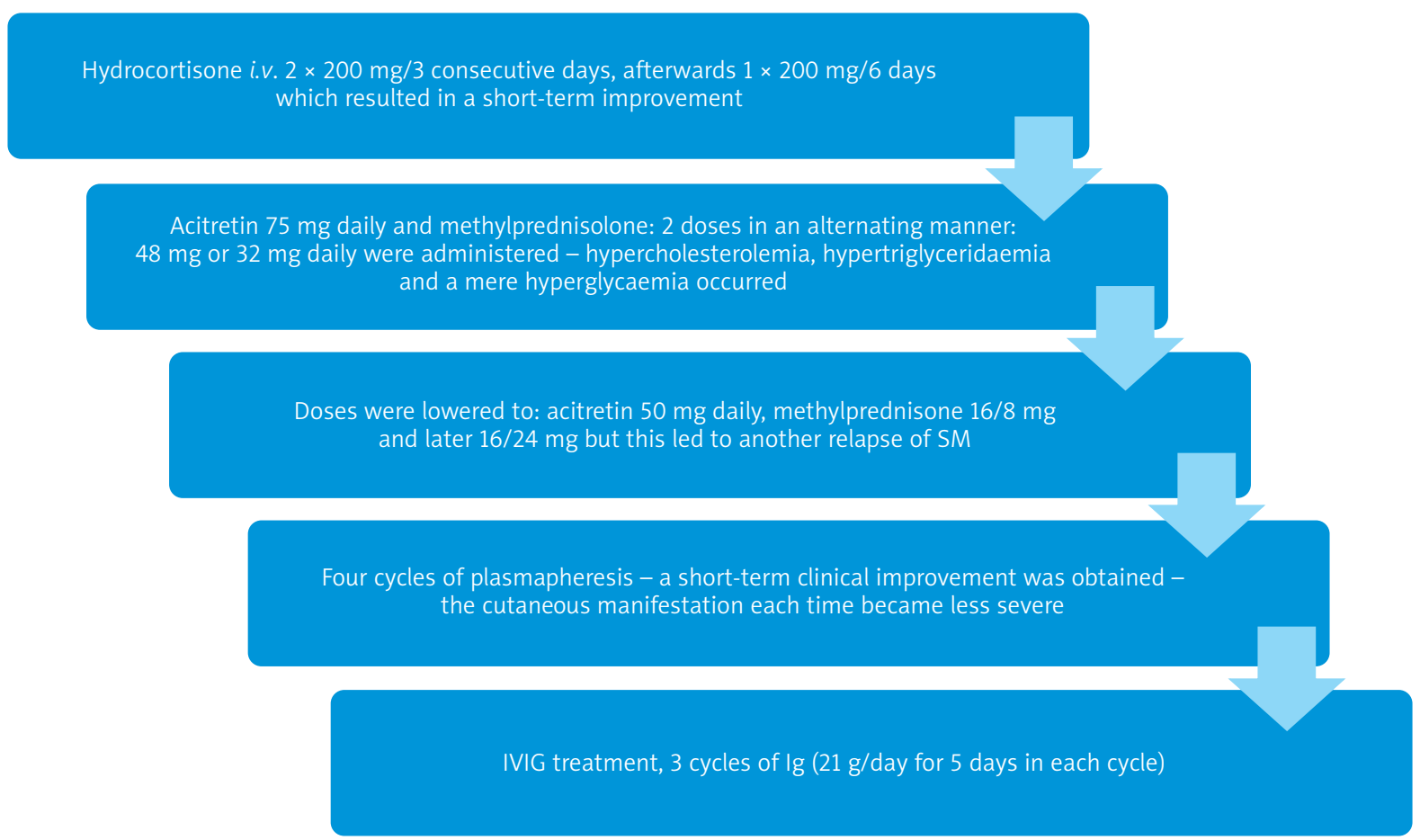

Figure 3. Different treatment modalities used in the therapy of our patient with scleromyxedema

Table 2. Treatment modalities of scleromyxedema

\begin{tabular}{lc}
\hline Treatment modality & References \\
\hline Systemic corticosteroids & {$[10]$} \\
\hline Cyclophosphamide & {$[11,12]$} \\
\hline Melphalan & {$[15]$} \\
\hline Interferon $\alpha$ & {$[16]$} \\
\hline Cyclosporine A & {$[17,18]$} \\
\hline Plasmapheresis & {$[19,20]$} \\
\hline Methotrexate & {$[21]$} \\
\hline Chlorambucil joined with PUVA & {$[22]$} \\
\hline Surgical intervention & {$[23]$} \\
\hline 2-chlordeoxyadenosine & {$[24]$} \\
\hline Retinoids & {$[25]$} \\
\hline Mucopolysaccharides (thiomucase) & {$[26]$} \\
\hline Thalidomide & {$[7,14]$} \\
\hline Immunoglobulins & {$[6,27-30]$} \\
\hline Autologous stem cell transplantation & {$[13,31,32]$} \\
\hline Biological treatment - bortezomib & {$[13,14]$} \\
\hline
\end{tabular}

phalan. Therapy before hospitalisation included oral prednisolone, oral antihistaminic drugs and topical steroids but remained ineffective. Treatment was started with hydro- cortisone i.v. $2 \times 200 \mathrm{mg} / 3$ consecutive days, afterwards $1 \times 200 \mathrm{mg} / 6$ days, which resulted in a slight improvement - erythema started to fade. After a relapse of the disease several weeks later, we introduced a combination of oral acitretin $75 \mathrm{mg}$ daily and methylprednisolone: 2 doses in an alternating manner $48 \mathrm{mg}$ or $32 \mathrm{mg}$ daily were administered. This stopped the progression of the disease. However, as a result of steroid and retinoid administration, the patient presented hypercholesterolemia, hypertriglyceridaemia and mere hyperglycaemia. This is why the doses were lowered to: acitretin 50 mg daily, methylprednisolone $16 / 8 \mathrm{mg}$ and later $16 / 24 \mathrm{mg}$, but this led to another relapse of clinical symptoms. Then, plasmapheresis was started. The patient received a total of 4 cycles of plasmapheresis. Each cycle consisted of 4-5 procedures of plasmapheresis. Every course resulted in short-term clinical improvement - cutaneous manifestation each time became less severe. In order to attempt to achieve remission, IVIG treatment was started (Figures 3 and 4).

\section{Discussion}

Causal treatment of scleromyxedema is unavailable, as the aetiology is still unclear [9]. The severe course of the disease requires very aggressive treatment and longterm maintenance therapy is necessary in most cases [7].

According to the literature, a successful therapy with relatively long-term effects and few side effects involves the use of IVIG $[28,29]$. It is considered to be the best ther- 

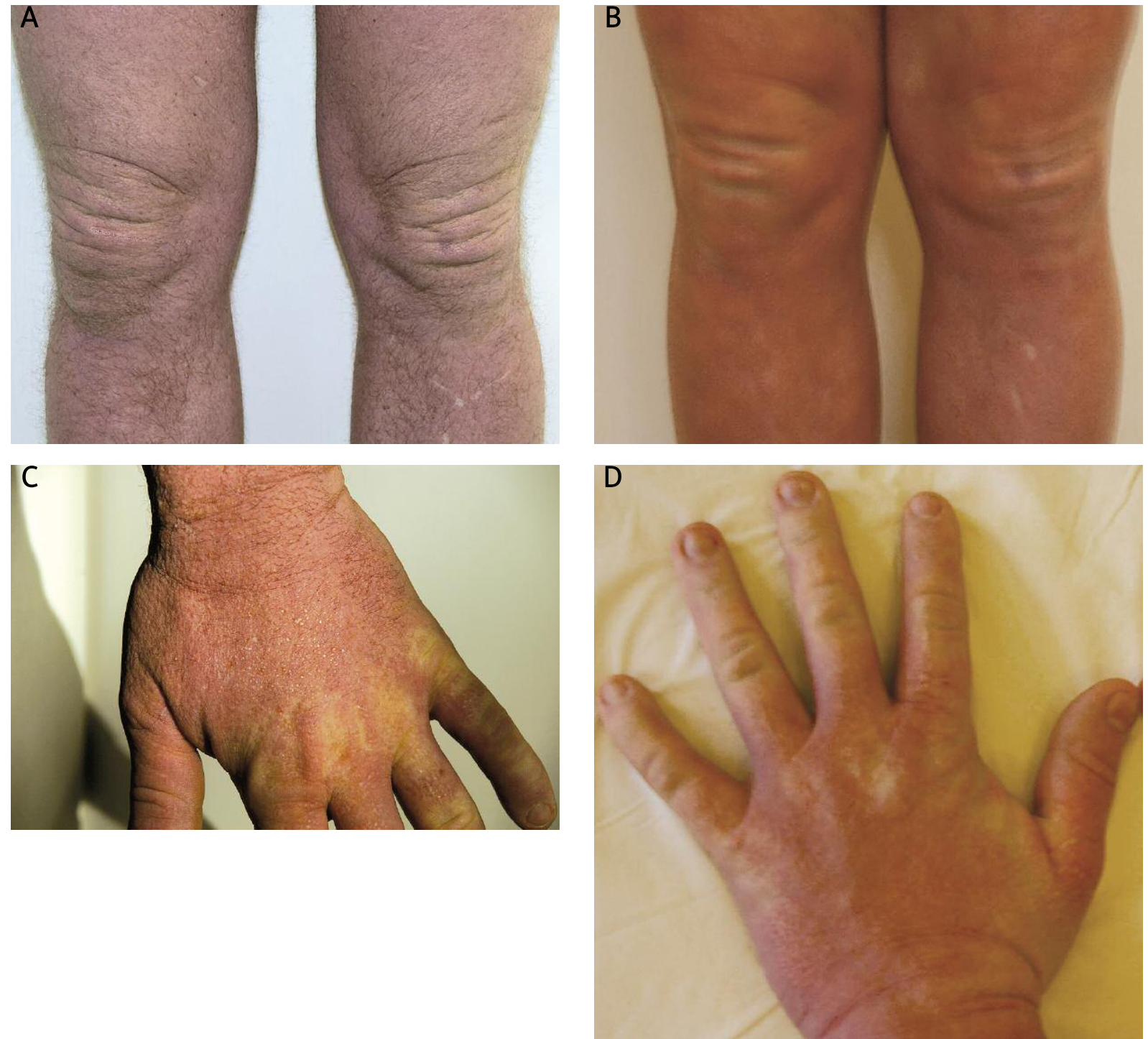

Figure 4 A-D. Clinical appearance directly prior to initiation of IVIG and after 3 cycles of IVIG - skin thickness deceased, papules became less visible

apeutic option as it is associated with relatively few side effects [27]. Plasmapheresis remains effective only in a short-time perspective and leads to relapses. For this reason we started IVIG treatment. We received a relatively good and longer lasting response to this treatment modality: the papules and generalised sclerodermoid eruption became less visible. The progression of the disease was stopped. However, from a financial aspect, this treatment modality may be challenging.

The chronic course of this disease affects the patient mentally, thus psychological or psychiatric therapy may also be introduced in order to improve the results of systemic treatment.

\section{References}

1. Brown-Falco O, Burgdorf WHC, Wolff HH, Landthaaler M. Dermatology. Czelej, Lublin 2011; 1289-90.

2. Rongioletti F, Rebora A. Updated classification of papular mucinosis, lichen myxodematosus and scleromyxedema. J Am Acad Dermatol 2001; 44: 273-81.

3. Serdar ZA, Yasar SP, Erfan GT, Gunes P. Generalized papular sclerodermoid eruption: scleromyxedema. Indian J Dermatol Venerol Leprol 2010; 76: 592-2.

4. Binitha MP, Nandakumar G, Thomas D. Suspected cardiac toxcicity to intravenous immunoglobulin used for treatment of scleromyxedema. Indian J Dermatol Leprol 2008; 74: 248-50.

5. Mehta V, Balachandran C, Raghavendra R. Arndt Gottron Scleromyxedema: successful response to treatment with steroid minipulse and methotrexate. Indian I Dermatol 2009; 54: 193-5. 
6. Manousaridis I, Loeser C, Goerdt S, Hassel JC. Managing scleromyxedema with intravenous immunoglobulin: accute worsening of scleromyxedema with biclonal gammopathy. Acta Dermatoven APA 2010; 19: 15-9.

7. Laimer M, Namberger K, Massone C, et al. Vincristine, idarubicin, dexamethasone and thalidomide in scleromyxedema. Acta Derm Venerol 2009; 89: 631-5.

8. Maciejewska-Radomska A, Sokołowska-Wojdyło M, Wilkowska A, et al. Scleromyxoedema in a 70-year-old woman: case report and review of the literature. Postep Derm Alergol 2011; 28: 63-6.

9. Kuldeep CM, Mittal AK, Gupta LK, et al. Successful treatment of scleromyxedema with dexamethasone cyclophophamide pulse therapy. Indian I Dermatol Venereol Leprol 2005; 71 44-5.

10. Rayson D, Lust JA, Duncan A, Su WP. Scleromyxedema: a complete response to prednisone. Mayo Clin Proc 1999; 74 481-4.

11. Aberer W, Wolff K. Scleromyxedema: immunosuppressive therapy with cyclophosphamide. Hautarzt 1988; 39: 277-80.

12. Kuldeep CM, Mittal AK, Gupta LK, et al. Successful treatment of scleromyxedema with dexamethasone cyclophosphamide pulse therapy. Indian J Dermatol Venereol Leprol 2005; 71: 44-5.

13. Migkou M, Gkotzamanidou M, Terpos E, et al. Response to bortezomib of a patient with scleromyxedema refractory to other therapies. Leuk Res 2011; 35: 209-11.

14. Cañueto J, Labrador J, Román C, et al. The combination of bortezomib and dexamethasone is an efficient therapy for relapsed/refractory scleromyxedema: a rare disease with new clinical insights. Eur J Haematol 2012; 88: 450-4.

15. Dinneen AM, Dicken CH. Scleromyxedema. J Am Acad Dermatol 1995; 33: 37-43.

16. Tschen JA, Chang JR. Scleromyxedema: treatment with interferon alfa. J Am Acad Dermatol 1999; 40: 303-7.

17. Krajnc I. Arndt-Gottron scleromyxedema. Summary of 2 years treatment. Wien Klin Wochenschr 1997; 109: 960-3.

18. Saigoh S, Tashiro A, Fujita S, Matsui M. Successful treatment of intractable scleromyxedema with cyclosporin A. Dermatology 2003; 207: 410-1.

19. Westheim Al, Lookingbill DP. Plasmapheresis in a patient with scleromyxedema. Arch Dermatol 1987; 123: 786-9.

20. Keong CH, Asaka Y, Fukuro S, et al. Successful treatment of scleromyxedema with plasmapheresis and immunosuppression. J Am Acad Dermatol 1990; 22: 842-4.

21. Mehta V, Balachandran C, Rao R. Arndt Gottron scleromyxedema: successful response to treatment with steroid minipulse and methotrexate. Indian J Dermatol 2009; 54: 193-5.

22. Schirren CG, Betke M, Eckert F, Przybilla B. Arndt-Gottron scleromyxedema. Case report and review of therapeutic possibilities. Hautarzt 1992; 43: 152-7.

23. Acikel C, Karagoz H, Kucukodaci Z. Surgical treatment of facial disfigurement due to lichen myxedematosus. Dermatol Surg 2009; 35: 875-7.

24. Davis LS, Sanal S, Sangueza OP. Treatment of scleromyxedema with 2-chlorodeoxyadenosine. J Am Acad Dermatol 1996; 35: 288-90.

25. Milam CP, Cohen LE, Frenske NA, Ling NS. Scleromyxedema: therapeutic response to isotretinoin in three patients. J Am Acad Dermatol 1988; 19: 469-77.

26. Cosgarea R, Cosgarea M, Turcu T. Scleromyxedema with laryngeal changes. Beneficial results of the treatment with mucopolysaccharidases. Ann Dermatol Venereol 1994; 121: 159-61.
27. Wojas-Pelc A, Blaszczyk M, Glinska M, Jablonska S.. Tumorous variant of scleromyxedema. Successful therapy with. JEADV 2005; 19: 462-5.

28. Blum M, Wigley FM, Hummers LK. Scleromyxedema: a case series of highlighting long-term outcomes of treatment with intravenous immunoglobulin (IVIG). Medicine (Baltimore) 2008; 87: 10-20.

29. Bidier M, Zschoche C, Gholam P, et al. Scleromyxoedema: clinical follow-up after successfu treatment with high-dose immunoglobulins reveals different long-term outcomes. Acta Derm Venereol 2012; 92: 408-9.

30. Righi A, Schiavon F, Jablonska S, et al. Intravenous immunoglobulins control scleromyxoedema. Ann Rheum Dis 2002; 61: 59-61.

31. Iranzo P, López-Lerma I, Bladé J, et al. Scleromyxoedema treated with autologous stem cell transplantation. J Eur Acad Dermatol Venereol 2007; 21: 129-30.

32. Illa I, de la Torre C, Rojas-Garcia R, et al. Steady remission of scleromyxedema 3 years after autologous stem cell transplantation: an in vivo and in vitro study. Blood 2006; 108: 773-4. 